INDEPENDENT JOURNAL OF MANAGEMENT \& PRODUCTION (IJM\&P)

http://www.ijmp.jor.br

v. 12, n. 2, March-April 2021

ISSN: 2236-269X

DOI: 10.14807/ijmp.v12i2.1154

\title{
INFLUENCE OF RELATIONAL RESOURCES ON THE DEVELOPMENT OF RELATIONAL OPERATING SKILLS
}

\author{
Fernando Nascimento Zatta \\ Mackenzie Presbyterian University, Brazil \\ E-mail: zatta@hmzconsulting.com.br \\ Elmo Tambosi Filho \\ Federal University of Santa Catarina, Brazil \\ E-mail:elmotf@hotmail.com \\ Rodrigo Randow Freitas \\ Northern University Center of Espírito Santo, Federal University of \\ Espirito Santo-UFES, Brazil \\ E-mail: rodrigo.r.freitas@ufes.br \\ Wellington Gonçalves \\ Northern University Center of Espírito Santo, Federal University of \\ Espirito Santo-UFES, Brazil \\ E-mail: wellington.goncalves@ufes.br \\ Rodrigo Ribeiro Oliveira \\ Federal Institute of Education, Science and Technology of São Paulo, \\ Brazil \\ E-mail: rodrigoribeirosp@hotmail.com \\ Liliane Cristina Segura \\ Mackenzie Presbyterian University, Brazil \\ E-mail: lilianecristina.segura@mackenzie.br
}

Henrique Formigoni Mackenzie Presbyterian University, Brazil E-mail: henrique.formigoni@mackenzie.br

Renata Schirrmeister Pontifical Catholic University of São Paulo, PUC/SP, Brazil E-mail: rschirrmeister@gmail.com

Submission: $10 / 27 / 2019$

Revision: $12 / 19 / 2019$

Accept: 6/8/2020

\section{ABSTRACT}

The debate about relational resources and their influences has followed an internal focus on organizations, and in the literature this has been shown to have a high influence on the ways of the resource-based view. 
INDEPENDENT JOURNAL OF MANAGEMENT \& PRODUCTION (IJM\&P)

http://www.ijmp.jor.br

v. 12, n. 2, March-April 2021

ISSN: 2236-269X

DOI: 10.14807/ijmp.v12i2.1154

This article aims to analyze the development of operational competencies following the focus of the relational view from the interaction of relational resources shared in supply chains. The research was guided by the strategy of multiple case studies in the steel industry, automotive and industrial applications, pulp production, and engineering for the energy industry. The results of the analysis of the four cases show that deeper relationships in the form of partnerships enable a process of investing in specific assets, knowledge accumulation, learning exchange, and a combination of complementary strategic resources that develop relational operational competencies. And, these competencies that represent the company's ability to promote a skill set to use resources efficiently and to provide a barrier to imitation are further developed by the information and knowledge constructs.

Keywords: Supply chain; Operational competencies; Operations management; Collaborative relationship; Resource-based view; Relational view

\section{INTRODUCTION}

In recent years, within the academic and managerial environment, theoretical perspectives in the field of Operations Management have sought to explain the development of competencies with an internal focus on organizations (Wernerfelt, 1984; Barney, 1991; Barney \& Clark, 2007; Barney \& Hesterly, 2011; Barney \& Hesterly, 2011; Grant, 1991; Amit \& Schoemaker, 1993; Collis \& Montgomery, 1995).

All are classic authors of the operations strategy literature. From these studies, we began to understand how internal resources can help business strategy, and as a derivation of internal resources, comes the relational view of the strategy focused on dyads, business network, and strategic alliances.

With regard to resources, Grant (1991), Barney (1991), Peteraf (1993), and Wu; Melnyk; Flynn (2010), emphasize the need to differentiate the concepts between resources and operational competencies, to obtain competitive advantages. Wu; Melnyk; Swink (2012) present a discussion of resources, practices, and competencies, arguing that operational competencies along with resources develop a barrier to imitation and are a potential source of competitive advantage (Wu, Melnyk \& Flynn, 2010).

It is noteworthy that with increasing competition over the last decades, a more relational view has emerged, prioritizing interorganizational relationships with the ability to create and sustain a business strategy (Balestrin, Verschoore \& Perucia, 2014). This view is corroborated by Zatta (2015), in order to develop competencies to compete in high competition 
INDEPENDENT JOURNAL OF MANAGEMENT \& PRODUCTION (IJM\&P)

http://www.ijmp.jor.br

v. 12, n. 2, March-April 2021

ISSN: $2236-269 X$

DOI: 10.14807/ijmp.v12i2.1154

environments. For this reason, companies seek to develop collaborative relationships to improve their operations management (Cao \& Zhang, 2011).

Ingham and Thompson (1994), Das and Teng (2000) and, Mesquita; Anand; Brush (2008) emphasize obtaining Relational Profits by creating or developing investments in relationship-specific assets, accumulating knowledge, sharing learning, complementing strategic resources, and developing relationships driven by governance mechanisms in situations that involve risk.

A relationship is realized when partners develop trust, involvement, social relations, communication, information, and knowledge for joint learning, recognizing that resource sharing generates relational incomes (Dyer \& Singh, 1998; Lavie, 2006; Wu, Melnyk \& Flynn, 2010).

The operational competencies developed in Operations Management are intended to structure and direct the use of shared resources between companies and leverage process improvement and operational performance (Voss, 1995; Narasimhan \& Swink \& Kim, 2005; Wu, Melnyk \& Flynn, 2010). Synergies developed in collaborative relationships yield greater benefits than if a company operated in the market individually (Cao, Zhang, 2011; Dyer \& Singh, 1998; Wu, Melnyk \& Flynn, 2010).

According to Dyer and Singh (1998), the relational approach (Relational View - RV) enables the relationship network in which the company operates, promotes productivity gains for business partners that make specific investments with unique combined resources (Asanuma, 1989; Dyer, 1996), about competitors who lack the ability to relate.

Thus, gaps on this topic are presented by recent research. For example, Wu; Melnyk; Flynn (2010) developed the concept of resources and competencies, from the company's internal perspective, that is, without considering resources and operational competencies created in the relations between companies. The theoretical review indicated that other studies, too, did not analyze which relational resources influence the development of operational competencies, shared in the supply chain.

As for Brazilian companies, they have a variety of internal resources available to be developed and/or used with those of other companies that have the ability to influence competency development (Wu, Melnyk \& Flynn, 2010). A variety of operational practices are required to achieve operations performance and develop distinct operational competencies. An enterprise can anticipate and develop operational practices and new operational competencies 
DOI: 10.14807/ijmp.v12i2.1154

that have critical strategic implications for resource allocation schemes and how these schemes affect operating performance (Wu, Melnyk \& Swink, 2012).

Thus, a key issue for operational competency development is: what relational resources influence the development of operational competencies, considering various resource categories and the various operational competency categories that represent the company's ability to promote a skill set to use resources efficiently?

Thus, the purpose of this article is to analyze the relational resources that influence the development of operational competencies that promote the skills needed to use resources efficiently. Thus, the discussion involves the interorganizational relationship, from the integration of perspectives from the field of internal and relational resources, involving operational competencies and collaborative relationships.

Empirical research conducted in companies in the steel, automotive and industrial applications, pulp production, and engineering for the energy industry aimed to explore this issue. The study is structured in five sections beyond this introduction. In the second, the theoretical foundation is presented; in the third section is the research framework; in the fourth, the methodological procedures of the research; in the fifth, the presentation and discussion of the research results are presented; and in the sixth and last section the research findings. The following is the literature review.

\section{THEORETICAL FRAMEWORK}

\subsection{Resource-Based View}

Resource-based view theory argues that competitive advantage can be gained by a firm through strategies for exploiting resources under its control in its business environment (Barney, 1991; Wernerfelt, 1984), consisting of an important stream of strategy (Penrose, 1959; Gohr et al., 2011).

In Resource-Based View, companies that have the potential to accumulate resources and competencies that are rare, valuable, irreplaceable, and hard to imitate will achieve sustainable competitive advantage over competitors (Wernerfelt, 1984; Barney, 1991; Grant, 1991; Amit \& Schoemaker, 1993; Collis \& Montgomery, 1995).

The traditional Resource-Based View argument refers to resources and competencies that are acquired, controlled, or developed internally by companies and that have sustainable competitive advantages. However, recent studies argue that relationships between companies 
DOI: 10.14807/ijmp.v12i2.1154

can also generate competitive advantages that derive from the interconnectedness of external resources and interrelated competencies with partner companies.

The traditional Resource-Based View was complemented by Dyer and Singh (1998), named Relational View, RV, and Mathews (2003), named Extended Resource-Based View, ERBV. The characteristics of relational features will be covered in the following section.

\subsection{Relational View}

Relational View, an expanded perspective of Resource-Based View, argues that a company's internal resources can be combined into relationships between companies across its borders, extending the resource-based view unit of analysis to the network of relationships and thus develop a relational competitive advantage (Dyer \& Singh, 1998).

In their seminal article on relational resources, Dyer and Singh (1998) argued that a company that does not have all the resources it needs to create competitive advantage will have to develop or combine its resources with those of other companies (Cao \& Zhang, 2011). The Relational View suggests that relational resources create additional relational incomes developed in relationship partner idiosyncrasies (Dyer \& Singh, 1998).

The present study follows the approach of Relational Vision defended by Dyer and Singh (1998), which aims, in the Operations Management area, to investigate relationships between companies that can generate competitive advantages from the acquisition of external resources and the development of competences. (Balestrin, Verschoore \& Perucia, 2014; Zen, 2010; Dyer \& Singh, 1998; Zacharia, Nix \& Lusch, 2011).

According to the Relational Vision, the relationship strategy creates inimitable sources of resources through a dyad/triad or company network by providing access to valuable information, knowledge sharing, resource complementarity, investment in relationship-specific assets, and effective governance (Balestrin, Verschoore \& Perucia, 2014).

This process is developed through relationship structure and scope to jointly access markets and develop an environment of innovation and improvement. As a result, the relationship is an imitable competitive collective resource, informational update, and reputation to empower new actions among members (Dyer \& Singh, 1998; Gulati, 1999; Balestrin, Verschoore \& Perucia, 2014).

Long-term relationships generate competitive advantage through four potential sources: investment in relationship-specific assets, substantial exchange of knowledge for shared 
INDEPENDENT JOURNAL OF MANAGEMENT \& PRODUCTION (IJM\&P)

http://www.ijmp.jor.br

v. 12, n. 2, March-April 2021

ISSN: $2236-269 X$

DOI: 10.14807/ijmp.v12i2.1154

learning, a complementary combination of resources, assets, competencies and skills, and lower transaction costs over time. relationship between competitors (Dyer \& Singh, 1998; Combs \& Ketchen Jr., 1999; Lavie, 2006).

Relational Vision is not just a way of exchanging or interacting resources, but a crucial and necessary condition for relative differences between partners to have value for the relationship. Regarding the value of the relationship, Mesquita, Anand, and Brush (2008) empirically tested the Relational Vision model and found that collaborative relationships between customers and suppliers have the potential for value generation contributing to relational performance resulting from the exchange of technical knowledge and shared use of specific assets. They also found evidence of the positive impact of the relationship on company performance due to inventory reduction, consumer satisfaction, agility, and efficiency in carrying out activities.

Resources are formed by tangible and intangible assets, for example, brands, technological knowledge, machines, plants, personal skills, among others (Wernerfelt, 1984). However, such resources alone only define the potential of the activity, they are passive and reactive (Wu, Melnyk \& Flynn, 2010). Operational skills, on the other hand, represent the company's ability to promote a personal skill set to effectively use these resources.

\subsection{Operational Competencies}

Operational competencies coupled with resources promote a barrier to imitation and act as a potential source of sustainable competitive advantage (Wu, Melnyk \& Flynn, 2010), achieved by outperforming competitors (Hayes \& Wheelwright, 1984; Voss, 1995; Laugen, Boer \& Frick, 2005).

Operations Management studies have focused on concepts and practical applications of operational competencies (Voss, 1995; Swink, Narasimhan \& Kim, 2005; Hayes et al., 2008; Wu, Melnyk \& Flynn, 2010; Santos, Gohr \& Varvakis, 2011; Zatta, 2015), being an approach that has been expanded with important contributions in the theoretical field for competitiveness.

Operational skills are a function of an organization's strategic commitment to process improvement (Tan, Kannan \& Narasimhan, 2007; Wu, Melnyk \& Flynn, 2010). The ResourceBased View (Penrose, 1959; Barney, 1991; Peteraf, 1993) provides the rationale for operational competences regarding the assumption of resource heterogeneity and suggests that operational 
DOI: 10.14807/ijmp.v12i2.1154

competencies are particularly relevant for creating primary income (Wu, Melnyk \& Flynn, 2010).

In the Operations Management literature, operational competencies are defined in different ways, with concepts generally interchangeable with resources and practices, without establishing differences and boundaries between them (Hayes et al., 2008; Wu, Melnyk \& Flynn, 2010). This is an open discussion, but one that has been a concern about what drives performance.

Thus, competencies have been defined as the ability to efficiently exploit existing resources (March, 1991), a category of organizational competencies aimed at performing basic functional business activities (Collis, 1995), daily problem-solving skills (Winter, 2003), ability to perform daily activities (Pavlou; Sawy, 2011), ability to explore the resource base through learning, process refinement, skills and incentives needed to repeat, leverage and sustain past successes (Martin, 2011), and the result of selection of resources and practices that allow activities to be carried out efficiency and efficacy (Paiva, 2017). The study by Wu, Melnyk, and Flynn (2010) conceptualized operational competencies as specific skill sets, processes, and problem-solving routines through resource configuration. This study adopts operational competencies as a consonant (Wu, Melnyk \& Flynn, 2010).

Thus, it is emphasized that operational competencies are a distinctive form of accumulated knowledge necessary for practical application in manufacturing operations and processes (Wu, Melnyk \& Flynn, 2010; Wu, Melnyk \& Swink, 2012; Flynn, Huo \& Zhao, 2010), solving problems, dealing with operational uncertainties, as they encompass explicit elements, such as resources and practices, and tacit elements, as know-how, skills, and leadership (Wu, Melnyk \& Flynn, 2010; Nonaka, 1994), and are tools to achieve predicted results (Voss, 1995; Swink, Narasimhan \& Kim Swink, 2005; Wu, Melnyk \& Flynn, 2010).

Based on the Operations Management literature, based on the initial study by Swink and Hegarty (1998) and Wu, Melnyk and Flynn (2010) developed a taxonomy of six operational competencies within the context of product differentiation whose objective is to provide a theoretical framework to guide its operationalization to solve business problems:

- Operational Improvements: These occur to incrementally enhance and enhance current operational processes and can contribute to the organization's innovation process (Swink \& Hegarty, 1998; Peng, Schroeder \& Shah, 2008); 
DOI: 10.14807/ijmp.v12i2.1154

- Operational innovations: occur through radical improvements to existing operational processes or the creation of new unique processes (Swink \& Hegarty, 1998; Peng, Schroeder \& Shah, 2008);

- Operational customizations: developed for knowledge creation and customization of operational processes (Wheelwright \& Hayes, 1985; Schroeder, Bates \& Junttila, 2002);

- Operational cooperation: Refers to the ability to develop stable relationships with internal functional areas and supply chain partners (Swink \& Hegarty, 1998; Droge, Jayaram \& Vickery, 2004; Escrig-Tena \& Bou-Llusar, 2005);

- Operational responsiveness: refers to the ability to react quickly and easily to internal and external changes (Upton, 1994; Swink \& Hegarty, 1998);

- Operational Reconfiguration: Refers to the ability to perform the transformation necessary to re-establish the fit between operations strategy arising from environmental contingencies (Teece, Pisano \& Shuen, 1997; Swink \& Hegarty, 1998; Pandža et al., 2003).

\subsection{Collaborative Supply Chain Relationships}

Changes in the dynamics of markets and organizations in recent years have prompted studies that argue for the need for collaborative relationships between companies and between the supply chain. The relevance of this relationship in the chain stems from increasingly global processes, for which companies are looking for more effective ways to coordinate material flow (Zacharia, Nix \& Lusch, 2011). In this context, chain collaboration improves operational performance reach and competitive advantage, in a situation of positive gains for the parties, which allows competition with other chains (Cao \& Zhang, 2011).

In the supply chain, collaboration is expressed as the combination of activities in which two or more autonomous companies work by joining efforts to plan and execute operations as a business process. Such an approach enables partners to add value through sharing information and communication, resources and risks, synchronized decisions and congruent goals, aligning incentives and knowledge creation, reducing costs and response time, improving resource efficiency and innovation (Burgess, Singh \& Koroglu, 2006; Cao \& Zhang, 2011).

For Gulati (1999) collaboration favors the creation of value for the chain as a whole, provides a competitive advantage and promotes benefits through the exchange of existing 
DOI: 10.14807/ijmp.v12i2.1154

knowledge and facilitates the creation of new knowledge, the combination, and codevelopment of resources and skills.

Thus, Bowersox and Closs (2001) and David and Stewart (2008) report that collaboration creates unique organizational and operational competencies when it includes the integration of knowledge and interorganizational cooperation, as suppliers and customers need knowledge regarding their position. they locate along the chain to leverage shared resources and assist in strategic decision making.

The Relational Vision approach allows us to state that interorganizational relationships produce information flows, create knowledge and learning with each other, resulting in relational income and competitive advantage as a complementary strategic resource (Dyer \& Singh, 1998; Hardy; Phillips; Lawrence, 2003 Jap, 2001; Vangen; Huxham, 2003).

Thus, companies increasingly seek to develop strategies along the length of the chain to achieve satisfactory performance (Krause et al., 1998; Tummala; Phillips; Johnson, 2006; Cao; Zhang, 2011; Chen; Paulraj, 2004), therefore, in the view of Rungtusanatham et al. (2003) is the supply chain that presents itself as an area that supports the application of different theoretical approaches to the understanding of how companies can develop value activities, coordination Irand control of joint actions (Lummus; Vokurka, 1999; Tan, 2002).

Increasingly deepened relationships stem from the external competitive environment that increasingly requires companies to engage in value activities in the business processes of the parties to the relationship (Cooper; Lambert; Pagh, 1997; Chen; Paulraj, 2004; Cao; Zhang, 2011).

\subsection{Research Framework}

To enable the analysis of the development of operational competencies, the proposed research model was anchored in the main constructs of resource theory, focusing on relational resources developed and/or shared in the relationships between supply chain companies, on the operational competencies' constructs. Operations Management area (Figure 1). 
DOI: $10.14807 /$ ijmp.v12i2.1154

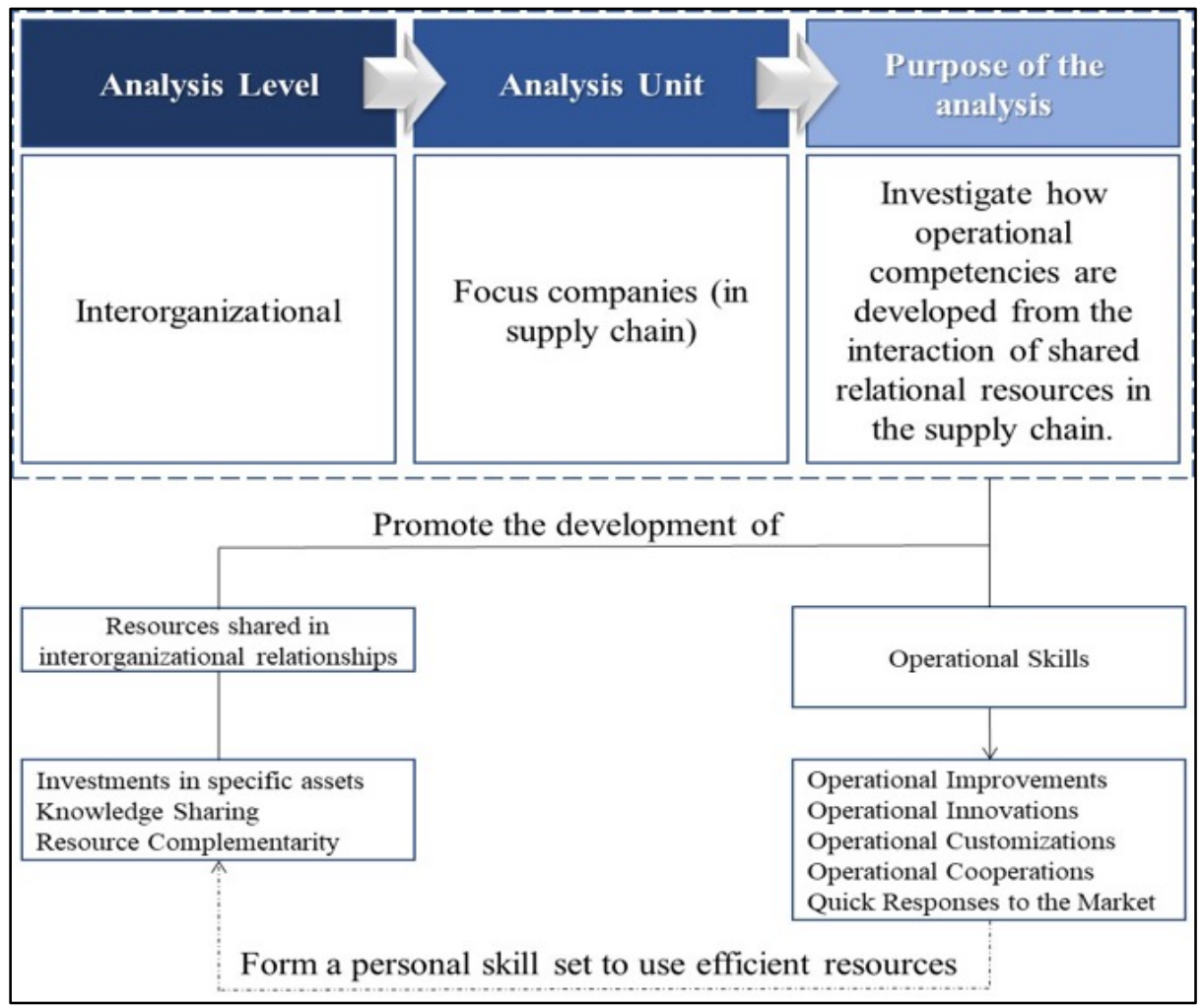

Figure 1: Research Framework of Interorganizational relationships. Source: Research data.

The relational view provided the basis for the analysis of how shared internal supply chain resources promote the development of operational competencies. In terms of dyads, we sought to understand how relational resources and operational competencies interact in order to analyze how these competencies are developed (Dyer \& Singh, 1998).

The Interorganizational relationships and the dynamics of competitiveness are based on the strategic actions undertaken to develop a competitive advantage based on resources developed and/or shared, but it is important to note that resources alone only define the potential to perform an activity, and use in isolation could be restricted to a small portion of companies.

Thus, because resources are passive and reactive and only define the potential of the activity, operational competencies are the set of personal skills and tacit knowledge to efficiently use such resources and create barriers to imitation and develop a competitive advantage. Although there is consensus in the literature that resources are key components of operational competency development, the ways in which a company's resources are used to achieve superior operational performance is mediated by operational competencies $(\mathrm{Wu}$, Melnyk \& Flynn, 2010).

\section{METHODOLOGY}


INDEPENDENT JOURNAL OF MANAGEMENT \& PRODUCTION (IJM\&P)

http://www.ijmp.jor.br

v. 12, n. 2, March-April 2021

ISSN: 2236-269X

DOI: 10.14807/ijmp.v12i2.1154

The choice of sectors and distinct industrial companies aimed to identify issues of complexity of the phenomenon investigated in each company, as well as make comparisons, in order to identify convergences and divergences between cases, given the specificities of each sector (Eisenhardt, 1989; Meredith, 1998).

The companies in the surveyed sectors were chosen due to their particularities, strategic position in the Brazilian and world scenario, level of employability, a world reference in competitiveness and income, and tax generation. The first company studied belongs to the steel industry and the second to the automotive applications sector, whose main client is the Brazilian and world automotive industry.

The initial data collection approach was performed through in-depth semi-structured interviews (Collis \& Hussey, 2005; Miguel, 2010; Lockstrom et al., 2011; Grötsch, Blome \& Schleper, 2013), and data were collected through a pre-tested roadmap and confirmed by academics and experts in Operations and Supply Chain Management. Thus, the answers were obtained from thirteen managers and specialists, who were selected regarding their knowledge - involving areas such as supply oversight, supply chain management, operations managers, planning and control management, Quality Analyst, Logistics Management, Human Resources, Procurement, and Process Engineering, and on the subject of research (Collis \& Hussey, 2005).

The interview script was prepared in three blocks: Block 1 - with six questions that characterize the profile of strategic suppliers; Block 2 - with six questions that characterize the collaborative relationship between focus companies and strategic suppliers; and Block 3 - with 17 questions related to relational resources and operational competences. The interviews lasted an average of one hour and forty minutes at each of the four companies, however, at the steel company (Alpha), data collection was carried out in two face-to-face rounds, and at the automotive and industrial applications company. (Gama), data collection was performed in three rounds. The total duration of the interviews was eight hours and twenty minutes.

The unit of analysis was the supply chain and the investigation took place on the focus side of the steelmaking (Alpha), automotive and industrial applications (Beta), pulp processing (Gamma), and flexible tube manufacturing and application segments (Delta). Thus, although the interview script was applied to the focus companies individually, the collected data reflect perceptions and initiatives adopted by the buyers and suppliers link and the nature of the relationship (Chen \& Paulraj, 2004). 
INDEPENDENT JOURNAL OF MANAGEMENT \& PRODUCTION (IJM\&P)

http://www.ijmp.jor.br

v. 12, n. 2, March-April 2021

ISSN: $2236-269 X$

DOI: 10.14807/ijmp.v12i2.1154

Due to the exploratory approach used in the operationalization and use of constructs (Miguel, 2010), we adopted the analysis of principal components for individual discussion and triangulation of results. Data analysis of multiple case studies was performed primarily by individual case analysis and then cross-comparative and case analysis.

Data evaluation followed the content analysis proposed by Bardin (1977) and the general analytical procedure proposed by Collis and Hussey (2005). This general analytical procedure adopted in data analysis includes the use of data interpretation and coding techniques, which allowed the systematic texts to be transformed into numerical variables that allowed the quantitative analysis of these data.

Thus, content analysis was used as the formal method of qualitative data collected in field research (Collis \& Hussey, 2005). The result of the content analysis was obtained through the following steps: (i) pre-analysis with the transcription of the interview reports with the researcher's perceptions and reflections, aiming at the data analysis and interpretation; (ii) data analysis and grouping into analytical categories. In this scenario, the assumptions of reliability and validity of the research were also used, which are criteria to judge the quality of the present study (Miguel, 2010), which Yin (2010) calls dimensions that should be adopted as points of attention to the patient. throughout the development of the research.

\section{RESULTS AND DISCUSSION}

\subsection{Main Characteristics Of The Relationship Between Supply Chain}

Qualitative assessment of the value activities of the focus companies in which strategic suppliers are involved comprised of research into the characteristics of the strategic supplier and the collaborative relationship with the focus company.

The value activities, in which strategic suppliers are involved that presented the greatest Provide questions and answers in the four investigated cases are: development of new products and management of the principles and guidelines of quality, applied in the focus companies processes (Cooper, Lambert \& Pagh, 1997; Chen \& Paulraj, 2004, Cao \& Zhang, 2011). There was also convergence between the results obtained in the companies Alpha and Gama, regarding the joint execution of production and inventory management.

The companies Beta and Gama, in turn, showed convergence, regarding the management of delivery times of raw materials. In general, it can be stated that, in the investigated cases, the collaborative relationship favors the exchange of information and knowledge sharing, which results in joint learning (Dyer \& Singh, 1998). 
INDEPENDENT JOURNAL OF MANAGEMENT \& PRODUCTION (IJM\&P)

http://www.ijmp.jor.br

v. 12, n. 2, March-April 2021

ISSN: $2236-269 X$

DOI: 10.14807/ijmp.v12i2.1154

All contracts are entered into to meet the supply needs of the focus companies, due to the high criticality of the products and the dependence on raw materials. Alfa uses commodity raw materials, and it is usual practice in the international market to contract advance purchases, which can be up to two years in advance.

Delta, which operates with flexible tubes, has as its purchasing strategy the formalization of long-term contracts, made for multi-annual periods (three years), adopting an advance pricing policy. Gama negotiates prices through a purchase agreement with wood producers in the domestic market. This was found to be a strong market feature.

However, respondents understand that the relative importance of the transactional mechanism is low; Relational characteristics are more present in the relationship, as they understand that the relationship provides greater opportunities to establish deeper relationships with strategic suppliers.

Collaborative activities are diverse, with the sharing and synchronization of business processes to acquire raw materials and components, obtain finished products, and distribute products to customers (Cao \& Zangh, 2011) are the most present. Focus firms have often been found to seek the sharing of goods, key equipment, intellectual property, as well as the transfer and creation of new knowledge.

The most commonly used shared relational resources are the investment in specific assets, information exchange, knowledge sharing, and complementary resources (Dyer \& Singh, 1998). Investment in specific assets in production facilities within the Alpha and Gama plants was identified by strategic suppliers. At Alpha, investments were made by suppliers unilaterally. It was found that the other relational mechanisms are more intense in the Alpha and Gama companies, showing that the structures of the steel and pulp sectors are more prone to resource sharing. This may be linked to the size of the companies, aspects related to the financial strength, and the ability to relate to the international market, among other aspects.

It is important to highlight the strong presence of relational mechanisms information exchange and knowledge sharing in the four cases investigated. It was found that tacit skills, experiences, and more qualified learning, resulting from the sharing of information and knowledge, were the resources considered most important for the performance of activities, whether relational or not.

Resource sharing linked to operational proximity and relationship duration has been found to build greater trust between partners, create relevant operational knowledge and skills 
INDEPENDENT JOURNAL OF MANAGEMENT \& PRODUCTION (IJM\&P)

http://www.ijmp.jor.br

v. 12, n. 2, March-April 2021

ISSN: 2236-269X

DOI: 10.14807/ijmp.v12i2.1154

to support internal processes and external relationships, resulting in the development of relational operational competencies (Dierickx \& Cool, 1989; Amit \& Schoemaker, 1993; Wu, Melnyk \& Flynn, 2010).

In the four cases investigated, it was revealed that the involvement and engagement of the senior management of the parties are fundamental to the success of the relationship, especially in the occurrence of informal relationships, because it generates greater trust for the relationship.

\subsection{Relationship Between Companies - Focus And Strategic Suppliers}

The relationship in the supply chain derives mainly from the characteristics of collaboration, regarding the level of involvement whether deep (relational characteristics) or superficial (transactional characteristics). Relational characteristics are more intense than transactional characteristics. It was evidenced that the adoption of the transactional relationship occurs so as not to interrupt the supply of supplies, especially of raw materials, however, it was revealed that this relationship does not affect the collaborative relations between the parties.

Corroborating Grant and Baden-Fuller (1995), it is found that the relationships of the focus companies with their strategic suppliers present a deep relationship level - partnership in which the companies work together, showing coalition in the accomplishment of common activities. The studied cases show that the collaborative relationship contributes in a major way to the relational mechanisms that overlap the transactional dimension. Respondents understand that the transactional mechanism is reduced, mentioning that companies rely much more on collaborative factors, engagement, and deeper and deeper interactions with strategic vendors. The following subsection presents the shared relational resources and operational competencies developed.

\subsection{Characterization Of Shared Relational Resources And Operational Competencies Developed Between Focus Companies And Strategic Suppliers}

In line with the objective of this study, which focuses on analyzing the development of operational competences from the interaction with relational resources, this subsection presents the results of the analysis of the research findings, considering the extent of value activities of focus companies in strategic suppliers are involved (Table 1), the characteristics of the collaborative interorganizational relationship (Table 2), and the patterns of the relationship between focus firms and strategic suppliers, discussed in the previous subsection. 
INDEPENDENT JOURNAL OF MANAGEMENT \& PRODUCTION (IJM\&P)

http://www.ijmp.jor.br

v. 12, n. 2, March-April 2021

ISSN: 2236-269X

DOI: 10.14807/ijmp.v12i2.1154

Table 1: Value activities of focus companies in which strategic suppliers are involved.

\begin{tabular}{|c|c|c|c|c|}
\hline & Alfa & Beta & Gama & Delta \\
\hline \multirow{10}{*}{$\begin{array}{c}\text { Value } \\
\text { activities of } \\
\text { focus } \\
\text { companies in } \\
\text { which } \\
\text { strategic } \\
\text { suppliers are } \\
\text { involved }\end{array}$} & Steel & $\begin{array}{l}\text { Automotive } \\
\text { applications }\end{array}$ & Pulp milling & Flexible hoses \\
\hline & Product & & & \\
\hline & Development and & New Product & New Product & New Product \\
\hline & $\begin{array}{c}\text { Process } \\
\text { Improvement }\end{array}$ & Development & Development & Development \\
\hline & Planning and & & Joint Production & \\
\hline & Production & & Execution & \\
\hline & Stock Processes & Order Tracking & Inventory Management & \\
\hline & Packaging Processes & $\begin{array}{l}\text { Managing Raw } \\
\text { Material Delivery } \\
\text { Times }\end{array}$ & $\begin{array}{c}\text { Managing Raw } \\
\text { Material Delivery } \\
\text { Times }\end{array}$ & \\
\hline & $\begin{array}{l}\text { Distribution } \\
\text { Logistics }\end{array}$ & & & \\
\hline & Quality Systems & Quality Systems & Quality Systems & Quality Systems \\
\hline
\end{tabular}

Table 2: Summary of key features and the way focus companies and strategic suppliers act collaboratively.

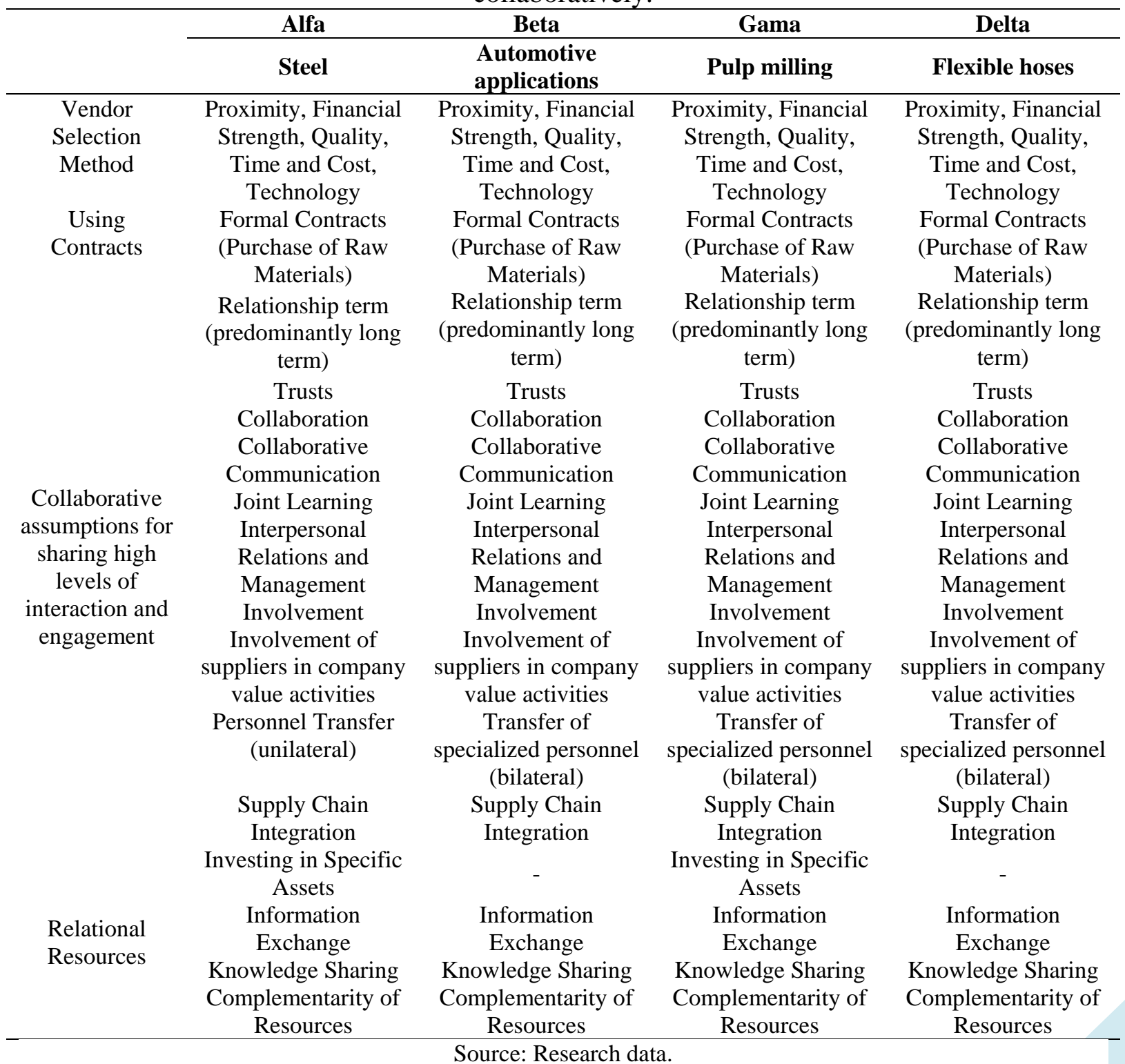


DOI: 10.14807/ijmp.v12i2.1154

The results highlight two important aspects:

- The category of relational resources shared between focus firms and strategic suppliers is class-based, relationship-specific asset investments, substantial knowledge exchange, including knowledge exchange that results in shared learning, resource complementarity, competencies and skills that result in the joint creation of new unique products, services, or technologies;

- Regarding the analysis of the operational competency category, there are six classes, composed of operational improvement, operational innovation, operational customization, operational cooperation, rapid market response, and operational reconfiguration. Specifically, operational reconfiguration competence was not identified in the data collection.

- The analysis then focuses on the role relational resources play in developing operational competencies in supply chains. To this end, the shared resources that have shown dynamism are:

- Investments in specific assets - consisting of investments made by suppliers in infrastructure, industrial plants, facilities and equipment (Alpha) and joint investments with suppliers in infrastructure, industrial plants, equipment, technology, trademarks and patents, financial resources, and resources human (Gamma). Beta and Delta companies do not make investments in specific assets with their suppliers;

- Information exchange - linked to supply chain performance, procurement information, raw material consumption, delivery times and related to value activities (Alpha); linked to supply chain, product improvement, cost structure, and supplier quality standards (Beta); linked to the supply chain, production, planning, and deadlines and related to value activities (Gamma); and linked to the supply and production chain and related to value activities (Delta);

- Knowledge sharing - with the strategic supplier on ways to use materials, operate equipment, improve processes, customize and develop new materials and products (Alpha, Beta, Gamma, and Delta);

- Combination of complementary resources - transportation systems development, logistics operators, raw material delivery, technical assistance services, research and 
DOI: 10.14807/ijmp.v12i2.1154

development, and an interorganizational alignment to harmonize systems and processes (Alpha, Beta, Gamma, and Delta).

- The operational competencies developed, here called relational operational competences are:

- Operational improvement - continuous improvement, waste elimination, waste, rework, inventory reduction, setup time reduction, development of new working methods, technical knowledge, and use of Six Sigma, Just In Time, and Total Quality Management, TQM (Alpha) tools. Continuous improvement, manufacturing with low levels of process variability, technological improvements, process standardization, cost reduction, quality and flexibility, technical expertise, and use of Six Sigma and TQM (Beta) tools. Continuous improvement, inventory reduction and setup time reduction, application of new knowledge in technical and operational resources to improve working methods, technical knowledge, and use of Six Sigma, Just In Time, and TQM (Gamma) methodologies. Continuous improvement and increase of technical knowledge, the introduction of new technologies and adjustments to those already developed, management of raw material use efficiency and management of receipt time, use of Six Sigma, Just In Time and TQM (Delta) tools;

- Operational innovation - development of new production processes combining joint work expertise and development of new products for specific customers (Alpha). Development of new products, systems, and processes continuously, testing of new products and new methods of simulation and testing of material laboratories (Beta). Investment in new technologies and product and process development (Gama). Development of experiments, tests, and analysis of error tolerance and product qualification (Delta);

- Operational customization - development of new equipment, adaptation of planning systems, modification of production processes for specific customers (Alpha). Development of products and solutions to meet specific sectors, specialization, learning, and knowledge developed with suppliers (Beta). Development of manufacturing processes for production flexibility (Gama). Product development to customer specifications, product application testing and computer simulation (Delta);

- Operational cooperation - information sharing to perform operational activities, joint decision making to solve supply chain problems, information sharing to deal with 
DOI: 10.14807/ijmp.v12i2.1154

uncertainties and to resolve cross-functional and inter-organizational conflicts (Alpha, Beta, Gamma, and Delta);

- Rapid market response - sharing information with suppliers to meet production orders, managing demand fluctuations, adjusting production capacity, changing process flows, changing inputs, labor, and equipment (Alpha, Beta, Gamma). Sharing information with suppliers to fulfill production orders, resource management, and production sequencing for volume flexibility (Delta) performance.

The development of competencies is carried out through an important research finding, which refers to the relevance of the information and knowledge and learning constructs, considered as significant relational resources for the development of operational competencies. These constructs generate learning based on jointly performing key operational routines and practices that develop supply chain specific experiences and skills.

Information facilitates collaborative activities, creates shared organizational and operational knowledge, and develops skills to build new competencies. Already, knowledge and learning develop innovation capacity, shorten the learning curve, and promotes higher innovation rates when companies share information and learning on a regular basis.

Technology, on a large scale, has been identified as crucial to the strategy for defect prevention, product and service quality improvement, cost reduction, and process variability.

For relationships with strategic suppliers, focus companies require expertise in product technology, processes, customized solutions, automation, and the ability to innovate, drivers of flexibility, and competitive costs. Technological innovations that relate to the product and/or process are made to meet specific customer needs.

In the investigated organizations, personalized training, experience exchange, and personnel transfer are required to address continuous improvements and changes in operational practices and processes, considering individual and collective skills to develop new processes, operate new equipment, match decision making, and align. cultural differences that may arise in the relationship.

\section{CONCLUSIONS}

Understanding the development of operational competencies from the interaction with relational resources opens new perspectives for Operations Management research and especially in the supply chain theme, by importing the supply chain. The consideration that 
INDEPENDENT JOURNAL OF MANAGEMENT \& PRODUCTION (IJM\&P)

http://www.ijmp.jor.br

v. 12, n. 2, March-April 2021

ISSN: 2236-269X

DOI: 10.14807/ijmp.v12i2.1154

internal resources and relational resources can influence competency development allows new understandings of the creation and pursuit of competitive advantages by the Operations area. In addition, this approach provides a breakthrough perspective in which the company's competencies evolve from an internal stage Provide theory.

From the definition of the central objective of the article and execution of the proposed framework, it was possible to explain how operational skills are developed from the interaction of relational resources shared in the supply chain and revealed that the information, knowledge and learning constructs have a direct influence on development specific set of collective skills to solve problems. Information, knowledge, and learning emerge broadly regarding other relational mechanisms, that is, the exchange of information and knowledge and learning are directly present in other relational resources and in the most diverse relational activities developed.

The results of this study contribute to extending the knowledge about the operational competences literature. Previous studies have assessed operational competencies and resources in other countries in non-industrial companies. This study finds that the decision to share rare and inimitable resources (manufacturing plant, equipment, knowledge, complementary resources) is related to the development of competitive advantages between companies, and the sharing of information, knowledge and learning is crucial to share superior relational gains to the parties in a sustainable manner over time. This is due to the use of collaborative relationships and synergies that promote learning and skills development for competency building from specific operating practices between companies that have common goals and share similar perspectives.

Therefore, long-term relationships based on trust and reputation produce less risk and uncertainty for partners to allocate their resources, which when combined provide greater gain than each party independently.

Therefore, when deciding to form collaboration, the buying companies require the selling companies to have experience in product and process technology, automation and innovativeness, flexibility, and competitive costs, in addition to operational proximity, financial strength, and ability to maintain relationships, predominantly established by longterm partnerships.

Finally, future analyzes may extend the analysis unit to strategic companies and suppliers, from the suppliers' perspective; for triads, networks and/or chains, involving companies, suppliers, 
INDEPENDENT JOURNAL OF MANAGEMENT \& PRODUCTION (IJM\&P)

http://www.ijmp.jor.br

v. 12, n. 2, March-April 2021

ISSN: 2236-269X

DOI: 10.14807/ijmp.v12i2.1154

and customers; and to investigate the role of operational competencies in the mediation between relational resources and operational performance.

\section{REFERENCES}

Amit, R., \& Schoemaker, P. J. H. (1993) Strategic assets and organizational rent. Strategic Management Journal, 14(1), 33-46.

Asanuma, B. (1989) Manufacturer-Supplier Relationships in Japan and the Concept of Relationship-Specific Skill. Journal of the Japanese and International Economies, 3(1), 130.

Balestrin, A., Verschoore, J. R., \& Perucia, A. (2014) The relational view of strategy: Empirical evidence from business cooperation networks. Revista de Administração e Contabilidade de Unisinos, 11(1), 47-58.

Bardin, L. (1977) Análise de conteúdo. Lisboa: Edições 70.

Barney, J. B. (1991) Firm resources and sustained competitive advantage. Journal of Management, 17(1), 99-120.

Barney, J. B., \& Clark, D. N. (2007) Resource-Based Theory: Creating and Sustaining Competitive Advantage. Nova York: Oxford University Press.

Barney, J. B., \& Hesterly, W. S. (2011) Administração Estratégica e Vantagem

Competitiva. 3. ed. São Paulo: Pearson Prentice Hall.

Barney, J. B., Ketchen Jr., D. J., \& Writht, M. (2011) The Future of Resource-Based Theory: Revitalization or Decline? Journal of Management, 37(5), 1299-1315.

Bowersox, D. J., \& Closs, D. J. (2001) Logística Empresarial: O Processo de Integração da Cadeia de Suprimento. São Paulo: Atlas.

Burgess, K., Singh, P. J., \& Koroglu, R. (2006) Supply chain management: a structured literature review and implications for future research. International Journal of Operations; Production Management, 26(7), 703-729.

Cao, M., \& Zhang, Q. (2011) Supply Chain Collaboration: Impact on Collaborative Advantage and Firm Performance. Journal of Operations Management, 29(3), 163-180.

Chen, I. J., \& Paulraj, A. (2004) Towards a theory of supply chain management: the constructs and measurements. Journal of Operations Management, 22(2), 119-150.

Collis, D. J., \&Montgomery, C. A. (1995) Competing on resources: strategy in the 1990s. Harvard Business Review, 73(4), 118-128.

Collis, J., \& Hussey, R. (2005) Pesquisa em administração: um guia prático para alunos de graduação e pós-graduação. 2. ed. Porto Alegre: Bookman.

Combs, J. G., \& Ketchen Jr., D. J. (1999) Explaining interfirm cooperation and performance: toward a reconciliation of predictions from the resource-based view and organizational economics. Strategic Management Journal, 20(9), 867-888.

Cooper, M. C., Lambert, D. M., \& Pagh, J. D. (1997) Supply Chain Management: More than a new name for Logistics. The International Journal of Logistics Management, 8(1), 1-14.

Das, T. K., \& Teng, B. S. (2000) A Resource-Based Theory of Strategic Alliances. Journal of Management, 26(1), 31-61. 
David, P., \& Stewart, R. (2008) Logística Internacional. São Paulo: Cengage Learning.

Dierickx, I., \& Cool, K. (1989). Asset stock accumulation and sustainability of competitive advantage. Management Science, 35(12), 1504-1511.

Droge, C., Jayaram, J., \& Vickery, S. K. (2004) The effects of internal versus external integration practices on time-based performance and overall firm performance. Journal of Operations Management, 22(6), 557-573.

Dyer, J. H. (1996) Specialized supplier networks as a source of competitive advantage: Evidence from the auto industry. Strategic Management Journal, 17(4), 271-291.

Dyer, J. H., \& Singh, H. (1998) The relational view: Cooperative strategy and sources of inter-organizational competitive advantage. Academy of Management Review, 23(4), 660679.

Eisenhardt, K. M. (1989) Building Theories from Case Study Research. Academy of Management Review, 14(4), 532-550.

Escrig-Tena, A. B., \& Bou-Llusar, J. C. (2005) A model for evaluating organizational competencies: An application in the context of a quality management initiative. Decision Sciences, 36(2), 221-257.

Flynn, B. B., Huo, B., \& Zhao, X. (2010) The impact of supply chain integration on performance: A contingency and configuration approach. Journal of Operations Management, 28(1), 58-71.

Gohr, C. F., Santos, L. C., Burin, C. B., Santos Marques, M., \& Arai, R. M. (2011) Recursos estratégicos e vantagem competitiva: aplicação do modelo VRIO em uma organização do setor sucroalcooleiro. Revista Gestão Organizacional, 4(1), 60-71.

Grant, R. M. (1991) The resource-based theory of competitive advantage: implications for strategy formulation. California Management Review, 33(3), 114-135.

Grant, R. M., \& Baden-Fuller, C. (1995) A knowledge-based theory of inter-firm collaboration. Academy of Management Journal, (1), 17-21.

Grötsch, V. M., Blome, C., \& Schleper, M. C. (2013) Antecedents of proactive supply chain risk management-a contingency theory perspective. International Journal of Production Research, 51(10), 2842-2867.

Gulati, R. (1999) Network location and learning: the influence of network resources and firm capabilities on alliance formation. Strategic Management Journal, 20(5), 397-420.

Hardy, C., Phillips, N., \& Lawrence, T. B. (2003) Resources, Knowledge and Influence: the organizational effects of interorganizational collaboration. Journal of Management Studies, 40(2), 321-347.

Hayes, R. H., Pisano, G. P., Upton, D. M., \& Wheelwright, S. C. (2008) Produção, Estratégia e Tecnologia. Em busca da vantagem competitiva. 2. ed. Porto Alegre: Bookman.

Hayes, R. H., \& Wheelwright, S. C. (1984) Restoring our Competitive Edge: Competing through Manufacturing. New York: Wiley.

Ingham, H., \& Thompson, S. (1994) Wholly-owned versus collaborative ventures for diversifying financial services. Strategic Management Journal, 15(4), 325-334.

Jap, S. D. (2001) Perspectives on joint competitive advantages in buyer-supplier relationships. International Journal of Research in Marketing, 18(1-2), 19-35. 
Krause, D. R., Handfield, R. B., \& Scannell, T. V. (1998) An empirical investigation of supplier development: reactive and strategic processes. Journal of Operations Management, 17(1), 39-58.

Laugen, T. B., Boer, N. A. H., \& Frick, J. (2005) Best manufacturing practices: what do the best performing companies do? International Journal of Operations \& Production Management, 25(2), 131-150.

Lavie, D. (2006) The competitive advantage of interconnected firms: an extension of the resource-based view. Academy of Management Review, 31(3), 638-658.

Lockstrom, M., Schadel, J., Moser, R., \& Harrison, N. (2011) Domestic supplier integration in the Chinese automotive industry: the buyer's perspective. Journal of Supply Chain Management, 47(4), 44-63.

Lummus, R. R., \& Vokurka, R. J. (1999) Defining supply chain management: a historical perspective and practical guidelines. Industrial Management \& Data Systems, 99(1), 1117.

March, J. G. (1991) Exploration and exploitation in organizational learning. Organization Science, 2(1), 71-87.

Mathews, J. A. (2003) Competitive dynamics and economic learning: An extended resourcebased view. Industrial and Corporate Change, 12(1), 115-145.

Martin, J. A. (2011) Dynamic Managerial Capabilities and the Multibusiness Team: The Role of Episodic Teams in Executive Leadership Groups. Organization Science, 22(1), 118-140.

Meredith, J. (1998) Building operations Management Theory Through Case and Field Research. Journal of Operations Management, 16(4), 441-54.

Mesquita, L. F., Anand, J., \& Brush, T. H. (2008) Comparing the resource-based and relational views: knowledge transfer and spillover in vertical alliances. Strategic Management Journal, 29(9), 913-941.

Miguel, P. A. C. (2010) (Org.). Metodologia de pesquisa em engenharia de produção e gestão de operações. Rio de Janeiro: Elsevier.

Narasimhan, R., Swink, M., \& Kim, S. W. (2005) An exploratory study of manufacturing practice and performance interrelationships: Implications for capability progression.

International Journal of Operations \& Production Management, 25(10), 1013-1033.

Nonaka, I. (1994) A Dynamic Theory of Organizational Knowledge Creation. Organization Science, 5(1), 14-37.

Paiva, E. L. (2017) Coevolução e competências operacionais: visão presente e oportunidades de pesquisas futuras. Revista Alcance, 24(2), 164-174.

Pandža, K., Polajnar, A., Buchmeister, B., \& Thorpe, R. (2003) Evolutionary perspectives on the capability accumulation process. International Journal of Operations \& Production Management, 23(8), 822-849.

Pavlou, P. A., \& Sawy, E. L. O. A. (2011) Understanding the elusive black box of dynamic capabilities. Decision Sciences, 42(1), 239-273.

Peng, D. X., Schroeder, R. G., \& Shah, R. (2008) Linking routines to operations capabilities: a new perspective. Journal of Operations Management, 26(6), 730-748.

Penrose, E. T. (1959) The Theory of the Growth of the Firm. New York: Wiley. 
DOI: 10.14807/ijmp.v12i2.1154

Peteraf, M. A. (1993) The cornerstones of competitive advantage: a resource-based view. Strategic management journal, 14(3), 179-191.

Tummala, V. M. R., Phillips, C. L. M., \& Johnson, M. (2006) Assessing supply chain management success factors: a case study. Supply Chain Management: An International Journal, 11(2), 179-192.

Rungtusanatham, M., Salvador, F., Forza, C., \& Choi, T. Y. (2003) Supply-chain linkages and operational performance: a resource-based-view perspective. International Journal of Operations \& Production Management, 23(9), 1084-1099.

Santos, L. C., Gohr, C. F., \& Varvakis, G. (2011) Um método para identificação e análise de competências e recursos estratégicos das operações de serviços. Gestão e Produção, 18(4), 791-808.

Schroeder, R. G., Bates, K. A., \& Junttila, M. A. (2002) A Resource-Based View of Manufacturing Strategy and the Relationship to Manufacturing Performance. Strategic Management Journal, 23(2), 105-117.

Swink, M., \& Hegarty, W. H. (1998) Core manufacturing capabilities and their links to product differentiation. International. Journal of Operations and Production Management, 18(4), 374-396.

Swink, M., Narasimhan, R., \& Kim, S. W. (2005) Manufacturing practices and strategy integration: Effects on cost efficiency, flexibility, and market-based performance. Decision Sciences, 36(3), 427-457.

Tan, K. C. (2002) Supply chain management: practices, concerns, and performance issues. Journal of Supply Chain Management, 38(4), 42-53.

Tan, K. C., Kannan, V. R., \& Narasimhan, R. (2007) The impact of operations capability on firm performance. International Journal of Production Research, 45(21), 5135-5156.

Teece, D. J., Pisano, G., \& Shuen, A. (1997) Dynamic capabilities and strategic management. Strategic Management Journal, 18(7), 509-533.

Upton, D. M. (1994) The management of manufacturing flexibility. California Management Review, 36(2), 72-89.

Vangen, S., \& Huxham, C. (2003) Nurturing collaborative relations: building trust in interorganizational collaboration. Journal of Applied Behavioural Science, 39(1), 5-31.

Voss, A. C. (1995) Alternative paradigms for manufacturing strategy. International Journal of Operations \& Production Management, 15(4), 5-16.

Wernerfelt, B. (1984) A resource-based view of the firm. Strategic Management Journal, 5(2), 171-180.

Wheelwright, S. C., \& Hayes, R. H. (1985) Competing through manufacturing. Harvard Business Review, 63(1), 99-109.

Winter, S. G. (2003) Understanding dynamic capabilities. Strategic Management Journal, 24(1), 991-995.

Wu, S. J., Melnyk, S. A., \& Flynn, B. B. (2010) Operational Capabilities: The Secret Ingredient. Decision Sciences, 41(4), 721-754.

Wu, S. J., Melnyk, S. A., \& Swink, M. (2012) An empirical investigation of the combinatorial nature of operational practices and operational capabilities: Compensatory or 
DOI: 10.14807/ijmp.v12i2.1154

additive? International Journal of Operations \& Production Management, 32(2), 121155.

Yin, R. K. (2010) Estudo de Caso: planejamento e métodos. 4. ed. Porto Alegre: Bookman. Zacharia, Z. G., Nix, N. W., \& Lusch, R. F. (2011) Capabilities that enhance outcomes of an episodic supply chain collaboration. Journal of Operations Management, 29(6), 591-603.

Zatta, F. N. (2015) Uma análise da influência dos Recursos Relacionais sobre as Competências Operacionais: estudo multicascos. 225 f. Santa Bárbara D`Oeste - Brasil. Tese (doutorado) - Universidade Metodista de Piracicaba, Programa de Pós-Graduação em Engenharia de Produção.

Zen, A. C. (2010) A influência dos recursos na internacionalização de empresas inseridas em clusters: uma pesquisa no setor vitivinícola no Brasil e na França. 270 f. Tese (Doutorado) - Universidade Federal do Rio Grande do Sul, Programa de Pós-Graduação em Administração. 